\title{
Use of Lysimeters to Evaluate the Atrazine Dynamics in Soil Cultivated with Maize
}

\author{
Affonso Celso Gonçalves Jr. ${ }^{1}$, Elio Conradi Junior ${ }^{1}$, Daniel Schwantes², Juliano Zimmermann; Guilherme \\ Lindner Ziemer'; Marcelo Angelo Campagnolo³; Andréia da Paz Schiller¹; Jéssica Manfrin'. \\ ${ }^{1}$ State University of West Paraná (UNIOESTE), \\ 1777 Pernambuco Street, Marechal Cândido Rondon, State of Paraná, Brazil. \\ affonso133@hotmail.com; elio.conradi@outlook.com; juliaanozimmermann@gmail.com; guilhermelziemer@gmail.com; \\ andreia.schiller@hotmail.com; jessicamanfrinn@gmail.com. \\ ${ }^{2}$ Pontificia Universidad Católica de Chile. \\ 4860 Vicuña Mackenna Avenue, postal code: 7820436 Macul, Santigo, Chile \\ daniel_schwantes@hotmail.com \\ ${ }^{3}$ Educational College of Medianeira, \\ 1820 Rio Branco Street, Medianeira, Brazil. \\ campagnolo.m@hotmail.com
}

\begin{abstract}
Despite the numerous studies reporting about pesticide interactions in inumerous environmental conditions, there is insufficient information relating their dynamics to the various textural classes of Brazilian soils and, consequently, the environmental problems caused by the use and application of these compounds. In this way, the objective of this study was to evaluate the atrazine dynamics through determination of the surface runoff and percolation in a Red Latosol cultivated with maize, through studies delineated in drainage lysimeter. Applications of atrazine at the recommended doses were performed weekly up to 44 days after emergence of the maize. Rainfall simulations $(150 \mathrm{~mm})$ were performed 24 and $48 \mathrm{~h}$ after each application, collecting samples of runoff and percolated water at intervals of $5 \mathrm{~min}$. The samples were sent to the laboratory for analysis of physical and chemical attributes and determination of atrazine concentrations by GC-ECD. Concentrations above the maximum values allowed by the regulatory agencies were found in approximately $99.16 \%$ of the obtained samples. The presence of atrazine in runoff and percolated water was recorded. Until 30 days after emergence (DAE) of the crop, higher concentrations of the pesticide were observed in the runoff $24 \mathrm{~h}$ after application, mainly in the initial collection minutes. In the percolated samples high concentrations of the pesticide were found even with the development of the crop, however, usually being smaller to those observed for surface runoff. There was a good correlation between the GUS (Groundwater Ubiquity Score) index and the GOSS model and the results obtained. It is concluded that there is the possibility of transporting atrazine in surface runoff and percolation in the different phenological stages of the maize crop when submitted to sequential applications and under high precipitation conditions.
\end{abstract}

Keywords: Environmental contamination, Pesticides, Lysimeter, Atrazine.

\section{Introduction}

In Brazil, the area farmed with maize in the 2018/2019 harvest reached approximately 16.8 million hectares, approximately 5.0 million in the first harvest and 11.8 million in the second harvest [1], placing the country among the top three world maize producers.

However, with the intensification of agriculture in 2008 Brazil surpassed the United States of America and became the largest consumer market for agrochemicals in the world. This position continues until today. Despite the numerous benefits to the humanity, such as gains in crop productivity and sanity, there is evidence that the use of pesticides can compromise the quality of different environmental compartments. It can represents a risk of surface water and groundwater contamination [2] and soil [3].

Among the pesticides used in maize crops is atrazine. It is a selective, systemic, pre-emergence and post-emergence herbicide used in the control of weeds, mainly in maize and sugarcane crops to control weed competition.

Although widely used in Brazilian agriculture, little is known about the dynamics of this molecule (atrazine) under field conditions using lysimeter and simulated rainfall. Therefore, the study is of great importance, both as regards to modern 
agriculture and to environmental aspects and to the assessment of the risk of water contamination. In this way, the objective of the present study was to evaluate the potential of atrazine transport through surface flow and percolation in an area cultivated with maize in the different stages of development of the crop and in a condition of intense precipitation.

\section{Material and Methods}

\subsection{Area of Study}

The field study is being developed using a drainage lysimeter installed in December 2013 in the area of the Protected Cultivation Station and Biological Control Professor Mário Cesar Lopes from the State University of the West of Paraná, Campus Marechal Cândido Rondon - PR - Brazil. The area is located under the geographic coordinates: latitude $24^{\circ} 55^{\prime}$ 80.86 " S and longitude 54 $04^{\circ}$ 57.45" W and altitude of $471 \mathrm{~m}$ in Red Latosol.

The lysimeter, made of $8 \mathrm{~mm}$ thick acrylic material and $1 \mathrm{~m}^{2}$ of base, contains an undisturbed soil sample of $1 \mathrm{~m}^{3}$. The sample is isolated laterally and in the background not allowing changes with the soil that gave rise to it.

In the downstream wall of the lysimeter, near the soil surface, there are 3 holes which, connected through flanges, collect the surface runoff and a hole near the base $(1 \mathrm{~m}$ depth) collects the leach flow. On it, a rainfall simulator was installed. The rainfall simulator allowed the control of precipitation intensity with the aid of a Davis® rain gauge with a Novus ${ }^{\circledR}$ data logger, which records precipitation data every $1 \mathrm{~min}$. In order to evaluate the granulometric and chemical characteristics of the soil, the composite sampling was carried out in a zigzag with the use of Dutch soil auger.

In the area, the corn crop, NS 50 PRO hybrid, was implanted on October 15, 2018. Seeds were conditioned at depth 3$5 \mathrm{~cm}$ by adopting spacing between lines of $50 \mathrm{~cm}$ with 3 seeds per linear meter being sown $\left(65,000 \mathrm{plants} \mathrm{ha}^{-1}\right)$, in conventional planting system.

\subsection{Aplication and Sampling}

After the emergence of the crop, the commercial product Siptroil ${ }^{\circledR}$ was applied, which has a concentration of $40 \%$ m.v ${ }^{-}$ ${ }^{1}$ of the active ingredient (atrazine). The dose used was $5.0 \mathrm{~L} \mathrm{ha}^{-1}$ of the commercial product, as recommended for use in crop. Weekly applications of atrazine were performed up to 40 days after emergence (DAE), which coincides with the Critical Period of Prevention of Interference (CPPI) of maize, that is, a period in which the crop of economic interest can not suffer any interference of weeds.

The rain simulations were performed 24 and $48 \mathrm{~h}$ after application of the pesticide, totaling 24 simulations. These rains correspond to pluviometric events of high intensity $(150 \mathrm{~mm})$, whose frequency of occurrence is low. Each rain simulation lasted $60 \mathrm{~min}$. The runoff and percolate samples were collected at 5 minutes intervals and stored in polyethylene bottles, packed in thermal insulation boxes and transported to the laboratory where they were immediately analyzed.

\subsection{Physical and Chemical Analysis in the Laboratory}

In the laboratory, analyzes of chemical and physical parameters of the water samples were carried out. It was determined the $\mathrm{pH}$ (pHmeter, W3B model) and electrical conductivity (conductivity meter - model 4303) of the samples. Also, It was determined the level of total solids (TS), fixed solids (FS) and volatile solids (VS), total nitrogen (N) and total phosphorus (P) were determined. Also, it was determined the levels of the metals potassium (K), calcium (Ca), magnesium (Mg), copper $(\mathrm{Cu})$, zinc $(\mathrm{Zn})$, iron $(\mathrm{Fe})$, manganese $(\mathrm{Mn})$, cadmium $(\mathrm{Cd})$, chromium $(\mathrm{Cr})$ and lead $(\mathrm{Pb})$ by atomic adsorption spectrometry (FAAS) [4].

Soil samples were submitted to chemical and granulometric analyzes. The granulometric analysis of soil samples for textural classification was performed using the pipette method [5]. The chemical analysis of soil fertility attributes was performed according to the soil chemical analysis manual recommended for the state of Paraná [6].

\subsection{Chromatographic Conditions}

The runoff and percolated samples were submmited to liquid-liquid extraction (1.5 mL MTBE: $15 \mathrm{~mL}$ water, shaking VIBRAX at $1000 \mathrm{rpm}$ for 2 hours), with subsequent determination of pesticide concentrations by GC-ECD (Adapted EPA 8141) [7].

The chromatographic conditions used for determination of atrazine concentrations by GC-ECD were: capillary column TR-5MS (5\% diphenyl and $95 \%$ dimethylpolysiloxane with $30 \mathrm{~m} \times 0.25 \mathrm{~mm}$ internal diameter $\times 0.25 \mu \mathrm{m}$ film thickness). The conditions of chromatographic analysis were: temperature of the splitless injector of $250^{\circ} \mathrm{C}$, initial temperature of the 
oven of $120^{\circ} \mathrm{C}$ with heating ramp of $5^{\circ} \mathrm{C} \mathrm{min}^{-1}$ to $200{ }^{\circ} \mathrm{C}$ and detector temperature of $300{ }^{\circ} \mathrm{C}$, drag gas flow $\left(\mathrm{N}_{2}\right)$ of $30.0 \mathrm{~mL}$ $\mathrm{min}^{-1}$ and split-stream of $2: 5$ in a run time of $20 \mathrm{~min}$.

\subsection{Assessment of contamination potential (GUS and GOSS)}

To evaluate the potential of leaching of pesticides to groundwater, it was used the method proposed by $[8,9]$ to determine the GUS (Groundwater Ubiquity Score) index. By means of this method the GUS index is calculated using the values of the organic carbon adsorption coefficient $\left(\mathrm{K}_{\mathrm{oc}}\right)$ and half-life ( $\mathrm{t} 1 / 2$ soil) of the pesticide, as presented in Equation 1 , being the result classified as follows way: a) GUS < 1.8 => Does not suffer leaching; b) $1.8<$ GUS < 2.8 => Transition Range; c) GUS > $2.8=>$ Likely leaching.

$$
\text { GUS }=\log \left(t_{1 / 2} \text { soil }\right) \times\left(4-\log \left(K_{o c}\right)\right)
$$

The method developed by GOSS [9] adopts the half-life of the compound in the soil (DT 50 in the soil), its solubility in water at $25^{\circ} \mathrm{C}$ and its soil organic matter adsorption constant $\left(\mathrm{K}_{\mathrm{oc}}\right)$ proposed to evaluate the potential of pesticides transport associated with sediment or dissolved in water to surface or groundwater.

Table 1: Criteria proposed by the GOOS method for assesssing the risk of water contamination [9].

\begin{tabular}{|c|c|}
\hline Groups & Characteristics \\
\hline 1 & $\begin{array}{l}\mathrm{t}_{1 / 2} \text { in soil } \\
\text {. }\end{array}$ \\
\hline 2 & $\begin{array}{c}\mathrm{t}_{1 / 2 \text { in soil }}<1 \text { day or } \mathrm{t}_{1 / 2 \text { in soil }} \leq 40 \text { days, } \mathrm{K}_{\mathrm{oc}} \leq 500 \mathrm{~cm}^{3} \mathrm{~g}^{-1} \text { and solubility } \geq 0,5 \mathrm{mg} \mathrm{L}^{-1} \text { or } \mathrm{t}_{1 / 2} \text { in soil } \leq 2 \text { days and } \mathrm{K}_{\mathrm{oc}} \\
\leq 500 \mathrm{~cm}^{3} \mathrm{~g}^{-1} \text { or } \mathrm{t}_{1 / 2 \text { in soil }} \leq 4 \text { days, } \mathrm{K}_{\mathrm{oc}} \leq 900 \mathrm{~cm}^{3} \mathrm{~g}^{-1} \text { and solubility in water } \geq 0,5 \mathrm{mg} \mathrm{L}^{-1} \\
\text { or } \mathrm{t}_{1 / 2} \text { in soil } \leq 40 \text { days and } \mathrm{K}_{\mathrm{oc}} \leq 900 \mathrm{~cm}^{3} \mathrm{~g}^{-1} \text { and solubility in water } \geq 2 \mathrm{mg} \mathrm{L}^{-1} \text {. }\end{array}$ \\
\hline 3 & $\begin{array}{c}\mathrm{K}_{\mathrm{oc}}>106 \mathrm{~cm}^{3} \mathrm{~g}^{-1} \text {, or } \mathrm{t}_{1 / 2 \text { in soil }}<1 \text { day and } \mathrm{K}_{\mathrm{oc}}<100 \mathrm{~cm}^{3} \mathrm{~g}^{-1} \text {, or } \mathrm{t}_{1 / 2} \text { in soil } \\
\mathrm{mg} \mathrm{L}^{-1}\end{array}$ \\
\hline 4 & $\begin{array}{c}\mathrm{K}_{\mathrm{oc}}>106 \mathrm{~cm}^{3} \mathrm{~g}^{-1} \text {, or } \mathrm{t}_{1 / 2} \text { in soil } \\
<1 \text { day and } \mathrm{K}_{\mathrm{oc}}<100 \mathrm{~cm}^{3} \mathrm{~g}^{-1} \text {, or } \mathrm{t}_{1 / 2} \text { in soil } \\
\mathrm{mg} \mathrm{L}^{-1}\end{array}$ \\
\hline 5 & Average potential of contamination \\
\hline
\end{tabular}

1 High surface water transport potential due to transport associated with suspended sediment; 2 Low surface water transport potential due to transportation associated with suspended sediment; 3 High transport potential of surface water due to being transported dissolved in Water; 4 Low surface water transport potential due to being transported dissolved in water; 5 Average potential contamination of surface waters due to being transported dissolved in water or associated with suspended sediment. Compounds that do not fit into any of the groups are considered to have average potential.

\section{Results and Discussion}

\subsection{Characterizations}

3.1.1. Matrix effect

In the chromatographic analyzes carried out, it is of great importance the knowledge of the effect that the matrix can cause in the determination of the analyte in question. In this way, runoff and percolated volumes were collected before pesticide application. A $15 \mathrm{~mL}$ aliquot of the liquid was sampled and accommodated in test tubes, adding $1.5 \mathrm{~mL}$ of MTBE, liquid-liquid extraction (10:1) and GC-ECD determination. As shown in Figures 1 and 2, no peaks were observed in time corresponding to the presence of atrazine, proving the absence of this molecule in the soil solution in the period prior to the beginning of the study. 


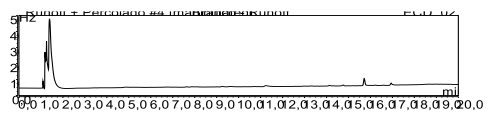

Fig. 1: Matrix effect of surface water runoff before pesticide application.

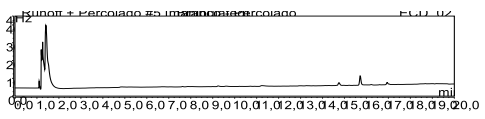

Fig. 2: Matrix effect of percolated water before pesticide application.

\subsubsection{Soil Samples}

The physical and chemical analyzes of the soil samples of the study area were carried out, whose results for chemical elements indicating soil fertility and $\mathrm{pH}$ are shown in Table 2.

It was determinated the parameters: $\mathrm{pH} \mathrm{CaCl}$, sum of bases (SB), saturation by bases (V\%), level of organic matter (OM), CTC, levels of $\mathrm{P}\left(\mathrm{Mehlich}^{-1}\right), \mathrm{K}^{+}, \mathrm{Ca}^{2+}, \mathrm{Mg}^{2+}, \mathrm{Al}^{3+}, \mathrm{H}+\mathrm{Al}, \mathrm{Cu}^{2+}, \mathrm{Zn}^{2+}, \mathrm{Fe}^{2+}, \mathrm{Mn}^{2+}$, levels of sand, silt and clay.

Table 2: Analytical results of fertility indicators in soils sampled.

\begin{tabular}{|c|c|c|c|c|c|c|c|c|c|c|c|c|}
\hline Sample & $\begin{array}{c}\mathrm{P} \\
\mathrm{mg} \mathrm{dm^{-3 }} \\
\end{array}$ & $\begin{array}{c}\mathrm{OM} \\
\mathrm{g} \mathrm{dm}^{-3}\end{array}$ & $\begin{array}{c}\mathrm{pH} \mathrm{CaCl} \\
0.01 \mathrm{~mol} \mathrm{~L}^{-1}\end{array}$ & $\mathrm{H}+\mathrm{Al}$ & $\mathrm{Al}^{3+}$ & $\mathrm{K}^{+}$ & $\begin{array}{r}\mathrm{Ca}^{2+} \\
\mathrm{cmol}_{\mathrm{C}} \mathrm{C}\end{array}$ & $\mathrm{Mg}^{2+}$ & SB & CTC & V & $\mathrm{Al}$ \\
\hline $\mathrm{ERL}^{1}$ & 32.24 & 17.09 & 5.77 & 2.57 & 0.00 & 0.72 & 4.22 & 1.15 & 6.09 & 8.66 & 70.32 & 0.00 \\
\hline
\end{tabular}

The evaluation of these parameters is fundamental to understand the dynamics of the molecules in the soil and the risk of contamination of surface and groundwater. It is known that the process of atrazine adsorption in the soil is deeply influenced by the composition, soil pH and amount of herbicide applied [10]. González-Márquez and Hansen [11] when evaluating the effect of soil parameters on the natural attenuation of atrazine concluded that the higher organic matter content observed generates the higher the atrazine adsorption.

Biodegradation of the molecule can also be influenced by soil fertility. Degrading microorganisms use atrazine as a source of energy and nutrients. According to Abigail [12], the presence of carbon and mineral nitrogen in the soil limits the biodegradation of atrazine, since microorganisms use the sources that are readily available for their metabolism, thus not using the pesticidal molecule as an energy source.

The levels of $\mathrm{Cu}^{2+}, \mathrm{Zn}^{2+}, \mathrm{Mn}^{2+}$ and $\mathrm{Fe}^{2+}$ founded in the samples are considered high, however, they are smallre than the limit allowed by Resolution $\mathrm{N}^{\circ}$ 420, of December 28, 2009 from Brazil National Council of Environmental (CONAMA) [13]. The levels of $\mathrm{Cd}^{2+}$ and $\mathrm{Cr}$ showed values smaller than the limit of quantification. In the other way, the levels of $\mathrm{Pb}^{2+}$ are higher can be originated from natural composition of the soil or human actions. 
Table 3: Content of metallic elements of agronomic importance and toxic metals present in soil.

\begin{tabular}{|c|c|c|c|c|c|c|c|}
\hline \multirow{2}{*}{ Sample } & $\mathrm{Cu}^{2+}$ & $\mathrm{Zn}^{2+}$ & $\mathrm{Mn}^{2+}$ & $\mathrm{Fe}^{2+}$ & $\mathrm{Cd}^{2+}$ & $\mathrm{Pb}^{2+}$ & $\mathrm{Cr}$ \\
\hline & & & & $\mu \mathrm{g} \mathrm{g}^{-1}$ & & & \\
\hline ERL & 10.9 & 12.2 & 130 & 36.2 & $<\mathrm{LQ}$ & 24 & $<\mathrm{LQ}$ \\
\hline
\end{tabular}

The results of the physical analyzes of the soil, whose objective was to determine the textural characteristics of the soil (sand, silt and clay) to determine the respective granulometry are presented in Table 4.

Table 4: Granulometric composition of the soil.

\begin{tabular}{|c|c|c|c|}
\hline & Clay & Silt & Sand \\
\hline Samples & 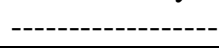 & $\mathrm{g} \mathrm{kg}^{-1}--$ & 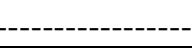 \\
\hline ERL & 477.00 & 314.08 & 208.92 \\
\hline
\end{tabular}

The values observed in Table 4 are characteristic of a Red Latosol, presenting high clay contents. In this way the soil of the study area can be classified as granulometry as Type 3 soil, or soil with a clayey texture, since it has a clay content higher than $350 \mathrm{~g} \mathrm{~kg}^{-1}$.

It is important to emphasize that the characterization of soil texture is another important factor in studies that aim to evaluate the dynamics of pesticide molecules in the soil and their potential for contamination of surface and groundwater. According to Wang \& Keller [14] the adsorption of atrazine in soils of clayey texture is higher when compared to soils of medium or sandy texture.

\subsection{Atrazine in water from runoff and percolated}

Samples of runoff and percolated water were analyzed by gas chromatography (GC-ECD). The results obtained are presented in Figure 2.

The Brazilian legislation through Ordinance $N^{\circ} 5$ of September 28, 2017, Annex XX of the Ministry of Health establishes the MAV (maximum allowed value) of $2 \mu \mathrm{g} \mathrm{L} \mathrm{L}^{-1}$ of atrazine in drinking water [15], for the water samples level, being the same value established by CONAMA of Resolution 357 [16]. In the European Union, the MAV of atrazine in drinking water is $0.1 \mu \mathrm{g} \mathrm{L}^{-1}$ [17] and in the USA it is limited to $3.0 \mu \mathrm{g} \mathrm{\textrm {L } ^ { - 1 }}[18]$.

The analytical results demonstrate the presence of atrazine in runoff and percolation. The samples from the runoff had atrazine concentrations between 320 and $252,060 \mu \mathrm{g} \mathrm{L}^{-1}$, while in percolated concentrations concentrations between 0.00 and $25.790 \mu \mathrm{g} \mathrm{L}^{-1}$ were found. Therefore, of the 240 water samples obtained, only two presented values within the limits established by the legislations cited above. It is noteworthy that in all the samples in which the herbicide was detected, the values found are higher than the legislation. 


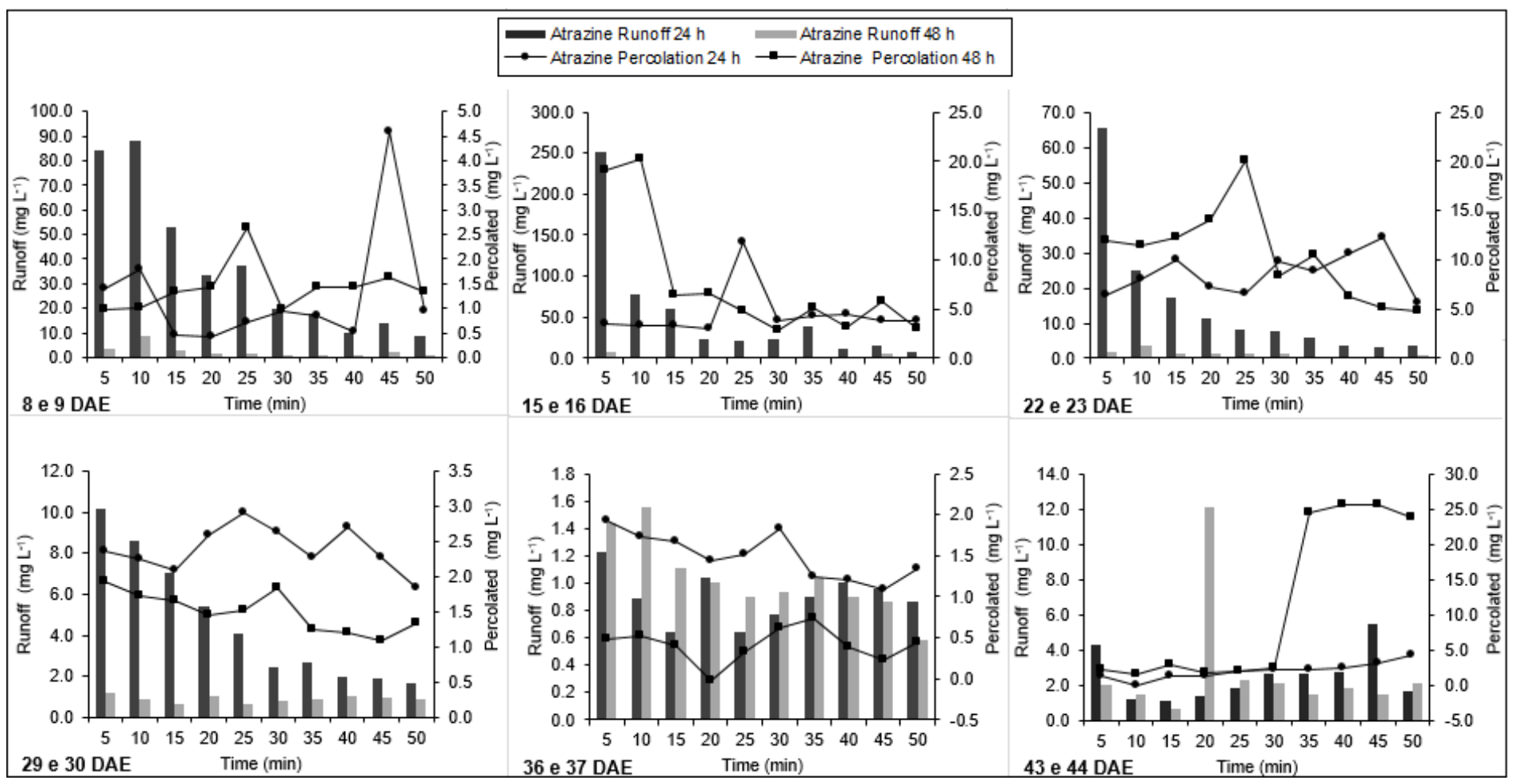

Fig. 3: Atrazine concentration in volumes of runoff and percolated obtained in maize crops with rain simulation (150 mm) in different phenological stages of the crop.

When analyzing the presence of the pesticide in the water samples throughout the different stages of development of the crop, it is observed that the concentration of atrazine in the samples collected up to 30 days after the emergency are higher in the runoff collected $24 \mathrm{~h}$ after the application of the pesticide when compared to the samples after $48 \mathrm{~h}$. In the 36 day period up to 44 days after the emergency, variations occurred sometimes obtaining after $48 \mathrm{~h}$ higher concentrations compared to the previous $24 \mathrm{~h}$.

Observing the time intervals presented in Figure 3, for the runoff samples collected after the first $24 \mathrm{~h}$, it is suggested that the highest concentrations of pesticides are found during the initial collection times and during the simulation the concentrations usually decrease. Observing the graphs obtained through the runoff after $48 \mathrm{~h}$, it is possible to observe a variation of concentration between the different collection times, not depicting uniformity. On the other hand, the analytical result of the percolate samples ( 24 and $48 \mathrm{~h}$ ) after application of the herbicide, demonstrates that there is no uniformity in the concentrations of atrazine found in different collection times. However, it is worth mentioning that even with the development of the crop high concentrations of atrazine are found in percolated samples at 43 and 44 DAE.

It is worth mentioning that the dynamics of pesticides in the environment is a result of environmental combinations and physical and chemical properties of the molecule. Atrazine shows high solubility in water at $20^{\circ} \mathrm{C}\left(35 \mathrm{mg} \mathrm{L}^{-1}\right), \log \mathrm{K}_{\mathrm{oc}}(100)$. The presence of atrazine in water may be related to the $\mathrm{K}_{\mathrm{ow}}$ and $\mathrm{K}_{\mathrm{oc}}$ index that the molecule presents, since these properties are directly related to the dynamics of the molecule in the environment. The $\mathrm{K}_{\mathrm{ow}}$ also known as octanol water partition coefficient, represents the lipophilicity of the molecule, with a 2.75 index for the pesticide in question, suggesting a high leaching potential [19]. This corroborates the finding of high concentrations of the molecule in runoff and percolated samples. On the other hand, $\mathrm{K}_{\mathrm{oc}}$ estimates the tendency of partitioning of the pesticide in the liquid phase to the soil organic matter [20], thus indicating the tendency of adsorption of the herbicide by the organic carbon present in the soil [21].

The physical and chemical properties of atrazine are shown in Table 1, which are used to determine the GUS index and GOSS method used to evaluate the dynamics of the pesticide molecule in surface and groundwater. 
Table 5: Physical and chemical properties of the active principle atrazine for the determination of the GUS and GOOS index [9].

\begin{tabular}{|c|c|c|c|c|}
\hline Active Principle & $\mathrm{K}_{\mathrm{oc}}(\mathrm{a})$ & $\mathrm{DT}_{50}$ soil (b) & $\mathrm{DT}_{50}$ water & $\begin{array}{l}\text { Solubility in water } \\
20{ }^{\circ} \mathrm{C}\left(\mathrm{mg} \mathrm{L}^{-1}\right)\end{array}$ \\
\hline Atrazine & 100 & 75 & 86 & 35 \\
\hline
\end{tabular}

(a) $\mathrm{K}_{\mathrm{oc}}$ : Coefficient of partition to organic matter $\left(\mathrm{mL} \mathrm{g}^{-1}\right)$ (b) $\mathrm{DT}_{50}$ : Time of half life [22]

The value obtained for atrazine using the GUS index is 14.6. According to the index, molecules with values greater than 2.8 are classified as pesticides that are likely to undergo leaching. Classification by the GOSS method suggests that atrazine is classified in the group of pesticides that present high transport potential of surface water due to being transported dissolved in water. It is observed that the classification according to GUS index and GOSS method corroborate with the data obtained in the present study, confirming that there is the possibility of atrazine transport in this soil class under the conditions employed.

It is important to note that the results found are similar to those observed by other researchers in different studies under different conditions. According to Dores [23] in a study conducted in oxisols, triazines have great potential for contamination of groundwater and surface due to their high solubility, persistence in the environment and low adsorption to soil. In a study carried out by Schimidt [24] the sorption and desorption of thiamethoxam and atrazine were evaluated in different management systems, using the experiment in a soil classified in clay dystroferric Red Latosol, which predominates clay in its constituents.

According to Silva and Azevedo [25], atrazine has a low vapor pressure and moderate water solubility. Therefore, in a water-soil system these herbicides present a moderate adsorption to the organic matter and clay, high persistence in soils, slow hydrolysis and a high potential of surface runoff. Due to this behavior, its residues can contaminate the soil and groundwater. In addition, the mobility of these compounds can be influenced by climatic conditions such as rainfall index and temperature, as well as intrinsic soil characteristics [26].

\section{Conclusion}

Concentrations above the maximum values allowed by the regulatory agencies (CONAMA/USEPA/European Parliament) were detected in approximately $99.16 \%$ of the samples obtained. The presence of atrazine in runoff and percolated water was recorded. Up to 30 days after emergence of the crop higher concentrations of the pesticide were observed in the runoff $24 \mathrm{~h}$ after application mainly in the initial collection minutes.

In the percolated samples, high concentrations of the pesticide were found even with the development of the crop, however, usually being smaller than those observed for surface runoff. There was a good correlation between the GUS index and the GOSS model and the results obtained. It is concluded that there is the possibility of transporting atrazine at runoff and percolation at the different phenological stages of the crop when submitted to sequential applications and under high precipitation conditions $(150 \mathrm{~mm})$.

\section{Acknowledgment}

This study was financed in part by the Coordenação de Aperfeiçoamento de Pessoal de Nível Superior - Brasil (CAPES) - Finance Code 001. The authors thank the Conselho Nacional de Desenvolvimento Científico e Tecnológico (CNPq) for the scholarship of productivity research.

\section{References}

[1] CONAB. "Boletim Monitoramento Agrícola", Brasília, vol. 8, no. 3, Mar., 2019, p. 1-20. [Online]. Available: http://www.conab.gov.br

[2] A. Pinheiro, V. Kaufmann, G. M. P. Queiroz, M. R. Silva, R. J. Bianco, "Transporte de glifosato pelo escoamento superficial e por lixiviação em um solo agrícola," Química. Nova., vol. 34, no. 2, pp. 190-195, 2011.

[3] A. Pinheiro, J. Moraes, M. R. Da Silva, "Pesticidas no perfil de solos em áreas de plantação de cebolas em Ituporanga," SC. Revista Brasileira de Engenharia Agricola e Ambiental-Agriambi, vol. 15, no. 5, 2011.

[4] B. Welz, M. Sperling, Atomic absorption spectrometry. John Wiley \& Sons, 2008. 
[5] Embrapa - Empresa Brasileira de Pesquisa Agropecuária. "Manual de Métodos de Análise de Solo," Rio de Janeiro: EMBRAPA-CNPS, 1997.

[6] INSTITUTO AGRONÔMICO DO PARANÁ, "Manual de análise química do solo e controle de qualidade," 1992.

[7] USEPA - United States Environmental Protection Agency, "Organophosphorus compounds by gas chromatography," EPA, 2007.

[8] D. I. Gustafson, "Groundwater ubiquity score: a simple method for assessing pesticide leachability," Environmental Toxicology and Chemistry: An International Journal, vol. 8, no. 4, pp. 339-357, 1989.

[9] D. W. GOSS, "Screening procedure for soils and pesticides for potential water quality impacts," Weed Technology, pp. 701-708, 1992.

[10] S. Hang, R. Sereno, "Adsorción de astrazina y su relación con las caraterísticas sedimentológicas y el desarrollo del perfil de dos suelos de la provincia de Córdoba," Ver. Investiga. Agropec., vol. 31, pp. 73-87.

[11] L. C. González-Márquez, A. M. Hansen, "Adsorción y mineralización de atrazina y relación con parámetros de suelos del DR 063 Guasave, Sinaloa,” Rev. Mex. Ciênc. Geológ., vol. 26, pp. 587-599, 2009.

[12] M. E. A. Abigail, V. Lakshmi, D. Nilanjana, D. "Biodegradation of atrazine by Cryptococcus laurentii isolated from contaminated agricultural soil," J. Microb. Biotechnol., vol. 2, pp. 450-457, 2012.

[13] CONAMA - Conselho Nacional do Meio Ambiente. Resolução 420, 28 de dezembro de 2009. Publicada no DOU ${ }^{\circ}$ 249, de 30/12/2009, pp.81-84, 2005.

[14] P. Wang, A. A. Keller, "Sorption and desorption of atrazine and diuron onto water dispersible soil primary size fractions," Water Res., vol. 43, pp. 1448-1456, 2009.

[15] Brasil - Ministério da Saúde. (2017). Portaria $n^{\circ}$ 5, de 28 de setembro de 2017. Publicada no Diário da União ${ }^{\circ} 190$. [Online]. Available: http://bvsms.saude.gov.br/bvs/saudelegis/gm/2017/prc0005_03_10_2017.html

[16] CONAMA - Conselho Nacional do Meio Ambiente. Resolução 357, 17 de março de 2005. Publicada no DOU nº 053, de 18/03/2005, pp.58-63, 2005.

[17] European Parliament, "On the quality of water intended for human consumption," Council Directive 98/83/EC., pp.3254, 1998.

[18] USEPA - United States Environmental Protection Agency (2003). Interim Reregistration Eligibility Decision for Atrazine. [Online]. Available: https://www3.epa.gov/pesticides/chem_search/reg_actions/reregistration/ired_PC080803_1-Jan-03.pdf

[19] A. Carmo, A. P. B. do Carmo, J. M. Bento Pires, J. L. M.Oliveira, "Comportamento ambiental e toxidade dos herbicidas atrazina e simazina," Ver. Amb. \& Água - An Interdiscipl. J. App. Sc., vol. 8, pp. 133-143, 2013.

[20] R. Pedroso, R. A. Neto, "Como o Koc, o Pka e o Kow influenciam na dinâmica de herbicidas no solo?," (2018) [Online]. Available: https://phytusclub.com/materiais-didaticos/como-o-koc-o-pka-e-o-kow-influenciam-nadinamica-de-herbicidas-no-solo/. Acesso em 11 de fevereiro de 2019.

[21] M. F. De Oliveira, A. M. Brighenti, A. M, "Comportamento dos herbicidas no ambiente," Embrapa Milho e SorgoCapítulo em livro científico (ALICE), 2011.

[22] IUPAC (2018). "International Union of Pure and Applied Chemistry," Atrazine. [Online]. Available: https://sitem.herts.ac.uk/aeru/iupac/Reports/43.htm. Acesso em 11 de fevereiro de 2019.

[23] E. F. G. C. Dores, L. Carbo, M. L. Ribeiro, M. L. E. M. De-Lamonca-Freire, E. M, "Pesticide Levels in Ground and Surface Waters of Primavera do Leste Region, Mato Grosso, Brazil," J. Chromat. Sc., vol. 46, pp. 585-590, 2008.

[24] T. D. Schmidt, J. C. Salton, "Sorção e dessorção de tiametoxam e atrazina em solo sob diferentes sistemas de manejo," Ver. Bras. Eng. Ag. Amb., vol. 19, pp. 613-618, 2015.

[25] T. R. Silva, D. A. Azevedo, "Monitoramento de atrazina, simazina e seus metabólitos no Complexo Estuarino Lagunar Mundaú-Manguaba, Alagoas," in Reunião Anual da Sociedade Brasileira de Química, vol. 31, 2008.

[26] T. G. Canuto, A. F. Gama, F. M. S. Barreto, M. F. A. Alencar Neto, "Estimativa do risco potencial de contaminação por pesticidas de águas superficiais e subterrâneas do município de Tianguá-CE, com aplicação do método de GOSS e índice de GUS," in Congresso Brasileiro de Águas Subterrâneas, vol. 16, no. 17, pp. 01-20, 2010. 